\title{
Reflections on the Internationalization of Higher Education
}

\author{
Lanyong Zhang*, Sheng Liu and Kai Tian \\ (College of automation, Harbin engineering university, Harbin, 150001, China) \\ *zlyalf@sina.com
}

Keywords: University; The Internationalization; Tactics

\begin{abstract}
The study elaborates the internationalization of higher education as well as the history of higher education internationalization in the ChinaChina in the general sense and the narrow sense, explores the experiences and process of international education between developed countries, and promotes the process of internationalization of higher education policy and several initiatives, in order to propel the process of internationalization of secondary college1.
\end{abstract}

\section{Introduction}

In the 18th Party Congress in 2012, building the moderately prosperous society and the goal of modernization of education has been proposed and the human resources are the important foundation to achieve this blueprint. Universities are responsible for training the talents with international perspective, the national spirit and innovative thinking. The method of education can determine whether the high school is the cradle of personnel and the power of science promoting. Development of foreign universities have gone through the "Internationalization - Nationalization International", and eventually established the "Internationalization" of the direction of development. "Internationalization" has become one of the features of world-class universities and has been necessary in development. Promoting the internationalization of the Higher Education is imperative.

Therefore, what is the "Higher School international connotation", what is the standard of international and the manner of behavior and what is the promotion of "the Higher Education internationalization" policy. Advanced preparation must been considered when facing the "internationalization" process.

The internationalization of higher education is composed of generalized and narrow sense. The connotation of international education is "the process of making the connection between the notion of cross-border, cross-culture and higher education, community services" [1]. Others pointed out that "the international education is the measure to deal with the globalization. It is an opening education based on respects culture and custom of domestic "[2]. "The narrow concept of higher school internationalization include international schools, international faculty, international curriculum, international influence and the proportion of foreign professors and students." [3].

\footnotetext{
Zhang Lanyong (1983 -), male, engineering, Ph.D., lecturer and director of the laboratory. He is mainly engaged in the related research in the field of control science and engineering. Address: Automation institute of automation engineering, Harbin engineering university. Telephone: 045182588758, postcode: 150001.
} 


\section{The Process of International Education in the China}

The internationalization of higher education in China has a long history, and it is a process of continuous development. It embodies that the Chinese higher education in the process of its development has a distinct international dating from the earliest private school in Spring and Autumn Period to the diplomacy of Sui and Tang dynasties to Ming dynasty and learning from foreign countries. However, Chinese international education has been in its infancy before the modern higher education was established.

Modern Chinese higher education is a typical model of "exogenous backwardness", its emergence and development process are influenced by external factors. From the historical development process, China's modern higher education has been changed when constantly absorbed and draw lessons from developed countries.

This process is roughly experienced the following stages: learned "Tessie" after the opium war in 1840 ; learned from Japan after the Sino-Japanese war; draw lessons from countries such as German's multivariate model; studied the Soviet model; completely closed during the cultural revolution and after the reform and opening up learned from other countries to seek a long process of development.

The establishment of the modern higher education system at the end of the 1970's was preliminary formation stage of internationalization of higher education in China. The establishment of the imperial university in 1898 marked the formal formation of modern higher education in the China. the China set up the first university through learning from Germany, Japan and other countries. After entering the 20th century, the establishment and development of higher education of the China raised a hot wave of learning western education along with a batch of universities such as Peking University and Tsinghua University were established. Later, the Cultural Revolution blocked the China's communication with others and made the international education suspended, thus gradually widened the gap with developed countries and made the higher education suffered a lot [4].

It can be seen that the internationalization of higher education is historically inevitable and also the only way for the development of China's higher education throughout the historical process of China's higher education internationalization. However, at present, the China's higher education internationalization degree is not good enough. As a country of modern higher education "exogenous backwardness ", researchers can enhance the comprehensive national strength and invincible position in world competition by implementing the internationalization strategy, making full use of the international quality education resources, absorbing the international advanced higher education experience, joining the international environment of higher education as soon as possible and cultivating international competitive ability of talents. This is the only way for China's higher education development in the 21 st century.

\section{The Internationalization of Higher Education in the Developed Countries}

Inte rnationalization of American Universities. America is an immigration country, attracting talents and service is a successive policy of Republican and Democratic parties. Universities are the frontier of attracting and gathering talents, so colleges are in the forefront of the policy. Thus, the internationalization of American's universities is the embodiment of the policy.

(1) The student's selection system and funding system for the world. The American education examination services launched the TOEFL and GRE exam, selecting talents for universities provided a unified standard during the last century. By 2008, the total number of applicants was more than 12 
million around the world, which only $5 \%-10 \%$ of the outstanding person can enter university study in the United States ${ }^{[5]}$.

(2) Attract talented foreign students by job opportunities and residence policy, especially for Ph.D. talents and encourage them to settle in the United States. American universities' internationalization promotes faster by the support of immigration policy and flexible employment system.

German Unive rsities' Internationalization Mode. Germany as one of the birthplace of higher education, its internationalization process has the following features:

(1) Set up the study and production center with the international enterprises and form a model of combining the universities, scientific research institutions and enterprises to integrate scientific research, product development and personnel training. University of Stuttgart, the Max Planck institute and Daimler Benz Company jointed and established the automobile technology center; University of Hamburg combined with ThyssenKrupp Company and set up a research center of advanced manufacturing system. Through the mode of production-teaching-research combination, colleges and universities are promoted to the international stage and into the international market by the enterprise scientific research.

(2) Establish international professional according to the government academic communication. According to the students needs to establish international professional, provide the natural science, environment, economy and sociology in areas with English and German work shops, launch the study consulting and coordinate students internship. Under the guidance of the specialized agencies, the German universities increasingly meet the demand of foreign students and the number of foreign students increased dramatically.

Japanese University International Policy. Japanese modern higher education started from Mingzhi period, it has referenced to other countries' education modes such as France, Germany and the United States for the development of domestic higher education ${ }^{[4]}$.

(1) Set the goal of internationalization and actively introduce advanced education concept, adjust the structure of subjects, perfect the talents' cultivation plan, reform the teaching contents and methods and accelerate the internationalization of higher education.

(2) Take the international research as the breakthrough point and then promote the internationalization process. Japanese universities regard the strengthening of international cooperation as an important task and actively carry out international research consisted of government, enterprises and universities to support scholars involved in international projects. Find the gap with competitive universities through the establishment of international cooperation projects.

\section{The Strategy of Internationalization of Higher Education in the China}

The internationalization of higher education in the China went through the twists and turns, in the current era of advocate internationalization, researchers must be actively thinking of the problems about what kind of idea and in what strategy to promote internationalization.

Updated the Concept of Strategy. Due to reasons known to all, China's university teachers and management personnel of international are lack of the conscience of internationalization. Participate in international cooperation and competition in the field of higher education, must firmly build up the international consciousness and update the concept of some long-term imprisonment.

First of all, researchers should update the concept of "talent" and review the talent training goal. In the last ten years, the training goal of higher education ignored the "internationalization". Second, update the teaching concept. In the past, people used to compare the teaching mode to "pull 
the both ends to the middle", that is, the whole teaching process is designed according to the medium level of the students' situation and its purpose is to ensure that all students can be qualified graduates. In this mode, those students with good foundation and potential can't be cultivated well and their innovative ability can't get development. In the mainstream of the market economy society, the graduates are generally lack of competition ability.

The System of Innovation Strategy. the current education system is including management system, operation system and in many ways can't adapt to the needs of the university internationalization. As a result, China's high-level university must reform the current system of education. Schools should establish and improve the flexible operation mechanism. The goal of reformation is to cope with the international competition. This aspect of the reform task should have:

(1) The internationalization of talent training mode. To be sure, internationalization is not completely follow. The internationalized talents training mode in this paper refers that the teaching plan of preparation technology and the design of curriculum should adopt the international common practice so that it is helpful to international communicate. The specific content of the teaching plan and courses should also fully consider China's national conditions as well ${ }^{[6]}$.

(2) The teaching content and teaching material to be internationalization. Internationalization of teaching material has two meanings: First of all, the teaching material content must be internationalized. Second, the teaching material compile mode to be internationalization. The main purpose is to break the thinking mode of pursuit the so-called "complete", "comprehensive" and "mature". New teaching material contents should be "concise", "characteristics" and "opening" so that make the teaching material a carrier of developing and opening knowledge system.

Talent Strategy. The universities are lack of the students with the ability to participate in the international cooperation and competition so that researchers need to gather the talents and organize an international teaching team. What researchers need is not only the teachers in the international high level but also the managements with international experience. At present, many universities attach important to absorb the high level teachers thus helps improving the quality of talents. While, ignoring the significant of management personnel will hinder the development of the school.

\section{A number of measures to promote the internationalization of university secondary academy}

Under the background of the internationalization of higher education, college as a secondary school principal, its internationalization progress influence the school education. Researchers need hold the concept of "cooperation, mutual benefit, win-win results, introduced the output, harmonious synchronization" and take effective measures to promote the internationalization process.

First, improve the international strength by the high level academic papers. Attach important to the high level papers and the cited frequency. This is not only prove the teaching and researching abilities but also value the academy discipline construction work. The high level paper is the first and direct way for foreign counterparts to acknowledge the research standard. Research results can be subject to the national counterparts through high level article published in the international authoritative magazine and conference and researchers can gradually promote the communication to accelerate the academic internationalization pace ${ }^{[6]}$.

Second, take the scientific research project as the platform to carry out the international cooperation. Invite and introduce the foreign scholars to accelerate the pace of internationalization. Learn the advanced technology by "absorb advanced concepts and advanced technology". 
Third, take the cultivating of young teachers as the main line and increase the intensity to send the teacher to study abroad. In the process of internationalization, researchers should cultivate and encourage the teachers to study abroad and absorb the advanced ideas in order to increase the strength of training and build the team with an international vision.

\section{Directions of higher learning education internationalization}

The internationalization of higher education has been evolved as a historical phenomenon or rather a historically inevitable way. Each policy makers have to face the problem of how to choose a road of the internationalization of higher education.

In order to guarantee the implementation of the "international", researchers must start from the source of the system and take the international factors into design ideas, finally, make the internationalize elements penetrated into all aspects of the job:

The construction of the higher education internationalization needs a lot of efforts, not only the enterprising spirit but also the unremitting efforts. Only in this way can Chinese universities ascend into the world and make progress.

\section{Acknowledgement}

This project is the key project in Heilongjiang province "The exploration and practice of the discipline construction of control science and engineering" (2011-16), "University teachers' scientific research team and scientific research achievements join into the innovative talent training mechanism of effective exploration and practice" (JG2013010202) and gained the Harbin engineering university undergraduate course educational reform project "school - enterprise - room research and practice of college students' scientific and technological innovation entrepreneurship system" (JG2014BYB13) funding. Planning Subject of Education Department of Heilongjiang Province (GBC1213103).

\section{Reference}

[1] Wu Yan quan. Internationalization of higher education and its thinking [J]. Journal of chongqing university, 2000). 73-76

[2] Yuping Zhong. The global economic integration and marketization of higher education development [J]. Journal of China university of education, 2000, 8, 40 - 41

[3] Wang Liushuan. The internationalization of higher education in the United States looking [J]. Journal of Shanghai higher education research, 1995 (3), 80-83

[4] Zhang Guo. To cope with the trend of internationalization of higher education in Chinese universities [J]. Journal of petroleum education, 2011, no. 4, 57-59

[5] ZhangGuang. The Japanese higher education internationalization process [J]. Journal of comparative education research, 1997, 2:10 - 13

[6] Sun Zhenglin. Universities' responsibility and mission in the construction of ecological culture [J]. China's higher education, 2011, 8, 6-8 
[7] Wang Bingqi Qiu Bizhen. Raise the level of the China university internationalization should handle the good relation [J]. China's higher education, 2011, 10, 18 -20

[8] Feng Huiling Hu Juan, HuiXinYu. The connotation of higher education internationalization, challenge orientation [J]. China's higher education, 2011, 11, 30 -31

[9] Xu Keyi yan-li guo, qing-mei wang. Graduate education internationalization and localization [J]. Journal of degree and graduate education, 2006, 2, 15 -19 